\title{
Epilogue: Post-classical Delphi
}

There is a tendency for the archaic and classical periods to be seen as the culmination of Delphic (and Greek) history, which is an outcome of the fact that these periods coincide with the most studied heyday of Greece history and literature. Although the short-sightedness of such approaches has been repeatedly criticised, it remains difficult to shed biases which prioritise Athenianand classical-era-centredness, a difficulty which is felt most acutely when one admits that classical Athens produced a treasure trove of historical evidence, against which we necessarily juxtapose every other polis from every other period of antiquity. In contrast to poleis which peaked in the classical era, the evidence concerning Delphi shows how the city continued to develop after the classical age and reached new heights in the Hellenistic and Roman eras; when Pausanias visited Delphi in the second century CE, it remained an important religious and cultural hub. In this volume it has been my intention, incomplete as it may be, to shed new light on Hellenistic and Roman Delphi, and, by making extensive use of hitherto unanalysed evidence, examine the dataset of Delphic honorific culture as an eye-opening case-study, offering new research avenues for scholars interested in Greek gift-giving systems, euergetism, and generally the Greek epigraphic tradition.

The development and character of the Delphic honorific culture sprang from the unique opportunities offered by Delphi's renowned oracular sanctuary and the fame and importance it conferred upon the city. A bustling and urbane polis, Delphi in the Hellenistic period attracted thousands of visitors from all over the Mediterranean, including pilgrims, athletes, theoroi, artists, 'men of letters' and tourists; this large and multiregional audience made Delphi a perfect location for those looking to display their generosity and wealth to the masses. Benefactions to the Delphic polis were rewarded with various honours: gifts, privileges, exemptions, celebratory inscriptions and material accolades, such as statues and portraits. Different factors vividly distinguish Delphic honorific culture among its counterparts. For example, there is (1) the sheer number and heterogeneity of recipients of Delphic gifts. Chapter 4 of this monograph discussed the analysed material sample - over 950 epigraphically recorded honorands, with a wide geographical and chronological scope, their hometown locations spanning from Massalia (modern Marseille) to Pantikapaion on the eastern shore of Kimmeria, and whose decree dates ranged from the early fourth century BCE up to the late fourth century CE. The second highly characteristic feature of the Delphic epigraphic habit is (2) the wealth and 
precise dating of the Delphic epigraphic evidence: a staggering number of no less than 3476 analysed texts of stone inscriptions, $93,5 \%$ of which are securely dateable to a specific century, and $78,7 \%$ to a quarter-century. Thirdly, there is (3) Delphi's unique blend of local (Delphic) and foreign honorific habits. The Delphic temenos equally displayed gifts of the Delphic polis, the Amphictyony, and other Greek and non-Greek agents. Finally, one may note (4) the evident Delphic predilection for abbreviated decree formulae (in lieu of full pattern documents, which were more popular elsewhere) and engraving decrees on building walls (in lieu of other conventional epigraphic media, such as stelai).

As this book comes to its close, it may be helpful to revisit some of its central arguments and themes. Chapters 2, 4 and, to some extent 1, proved that honorific culture at Delphi was never static. Granted honours and their recipients changed over time as the Delphic honorific system shifted to adapt to the changing social milieu. The Roman subjugation of Delphi greatly impacted preferred types of honorands and bestowed gifts, as the Delphians had to alter long-established political and epigraphical habits to comply with Roman expectations. As a rule, the Greek epigraphic habit initially focused on celebrating gods, with dedications and votive offerings the first type of inscriptions to appear also in Delphi in the sixth century в СE and to remain popular throughout the next century. Over time, the tradition at Delphi and other poleis shifted to accommodate non-divine honorands; poleis employed decrees to commemorate external benefactors, Hellenistic kings, royal officials, and various types of artists and athletes. From the mid-fourth century вСE until the start of the common era, the Delphic gift-giving system primarily celebrated foreign male benefactors from all over the Mediterranean world. After the Romans dominated the Delphic political landscape and the Greek peer-polity interaction declined, the Delphians preferred to honour prominent Romans and Delphian elite citizens. From the second century в CE onwards, Delphi began to honour women, most of whom were commemorated in the second century CE. This adjustment resulted, inter alia, in wide-ranging modifications to the Delphic gift-giving system; decrees that were typical of Hellenistic Delphi were largely replaced by tituli honorarii of the imperial era. The decisive factor for the changing nature of the epigraphic habit must have been the growing preference for monumental honorary forms among the honoured Romans and municipal elites.

My investigation into Delphi's relations with the Hellenistic monarchs has demonstrated that, despite its attempts at fostering a wide network of reciprocal relationships with honorands from all over the Mediterranean, Delphi had weak links with the main Hellenistic powers and played a marginal role in the politics of the day. In this context, I have argued that the key issue is to 
define what we mean by 'politics'. Delphi issued numerous proxeny decrees in the third and second centuries: by establishing ties with its proxenoi from Greek city-states and non-Greek communities, Delphi confirmed its status as a central religious and cultural authority among Mediterranean communities. From this it is clear that the Delphians, by starting to publish honorific decrees on stone, were doing their best to use the epigraphic medium to forge alliances in a world where a medium-sized polis could amass symbolic capital but had little to no diplomatic leverage.

The body of evidence discussed in Chapter 2 has revealed the existence of trends and rhythms in gift-giving at Delphi. Voted gifts evolved from the standard package consisting of proxenia, promanteia, proedria, prodikia, asylia and ateleia, which was characteristic of Hellenistic Delphi, to statues as the most common award in the Roman period. Both the popularity of particular honours and their respective value changed over time, with the amassed material shedding some light on the process of prestige deflation and axiological hierarchies of honours. Gifts granted to Delphic benefactors in the classical and Hellenistic periods seem more socially-valued and diverse than those granted in the Roman era. By the Augustan era, grants of promanteia, proedria and ateleia became a rarity; theorodokia, invitations to the prytaneion and xenia were no longer granted; honours such as proxenia, raising statues and awards of grants of citizenship lost much of their former esteem. Among these honours, the relative worth and appeal of statues suffered most.

Studies on gifts for citizens and non-citizens showed a series of notable patterns. Citizens of Delphi, in contrast to foreigners, were eligible for fewer types of gifts, since they could not be granted politeia or proxenia. My analysis of the honorific habit has indicated that the Delphians had no interest in receiving honours which were designed to bestow civic privileges on foreigners (e.g. prothysia, epitimia or isopoliteia), since the Delphians already enjoyed these rights by virtue of their citizenship. Similarly, the Delphians already had the right of precedence in access to their oracle (promanteia). In the Hellenistic period, no Delphic citizen received Delphian privileges, since all Delphians enjoyed the same prerogatives, obviating the need for additional gifts. In the imperial period, with its ongoing oligarchisation, the situation changed and many members of the Delphic elite received Delphic honours. Roman Delphi witnessed growing inequality as its citizenry stratified and its level of civic privilege diversified. Honorific images set up in the imperial period for local elite members were intended to reinforce the social and political superiority of local aristocrats (super-citizens) in comparison to regular citizens. Therefore, we are entitled to conclude that changes in publishing and honorific habits went hand in hand with changes in political culture at Delphi. 
As Mack has rightly noted, to be a polis was to be one among other poleis and to engage in inter-polis interaction. ${ }^{1}$ In other words, any city aspiring to be a part of the Greek world had to create a functioning social network. The universal human need for connection and cooperation may be expressed through different means and channels: just as modern nations employ the internet to express themselves through social networking websites and multi-platform messaging apps, so the ancient Greeks cultivated preventative and cooperative relationships with other poleis through their complex honorific systems. For a significant period of time, systems such as festivals, proxeny and citizenship networks constituted the best instruments to engender relations between poleis. The use of network theory as a methodological tool in Chapter 3 allowed Delphic history in general, and the award of proxeny in particular, to be viewed through different lenses than was previously possible. The key question of Chapter 3 concerned the unprecedented number of proxeny decrees granted at Delphi in comparison to other Greek cities. I have argued that Delphi's rather weak economic situation influenced the unprecedented integration with other Greeks, since it was the pilgrims to the temple that feed the local inhabitants.

Moreover, the Panhellenic renown of the Delphic shrine and its festivals attracted visitors from all Mediterranean communities, making Delphi the ideal spot to flaunt one's status. It therefore seems likely, as I have argued, that, when a proxeny decree was issued in Delphi, it had a much better chance of being publicised on one of the Delphic walls than outside the city. Visitors would see that becoming Delphic proxenoi paid off, as in Delphi they made grants visible. This increased the number of wealthy benefactors who willingly became proxenoi of Delphi. Proxenia inscribed within the Delphic temenos served as a proleptic honour, whose task was to encourage other benefactors to put in the effort and gain the honorific title of Delphic proxenos through their benefactions. The system of inscribing honours encouraged people to spend large sums of their private fortunes on the city. This in turn fuelled both a race for honours as proxenia came to function as a prize in euergetic contests and a rivalry between urban elites to gain higher honours outside their own city. The Delphians knew that the role of decrees was to communicate honours and portray relationships, and that the publication of texts of honorific decrees would prompt the cosmopolitan crowd to make further benefactions. Proxeny decrees were not only published in visible places so they could be seen by large numbers of visitors, but their placement was also intended to make an impact on the international audience and stimulate the race for honours. In this way the Delphians shrewdly built on international rivalries to stoke fires of envy

1 Mack 2015, 285. 
and attract further benefactions. Similar practices were also observed in material from Delos and Athens.

In Chapter 3, I proposed that, in contrast to other Greeks, the Delphians inscribed if not all, then at least the majority, of their honorific decrees, which explained the inordinately high number of preserved proxeny documents at Delphi. This was possible through the use of both building walls as the prime medium for inscriptions and an abbreviated form of decrees that reduced the cost of inscribing decrees to a minimum. Moreover, I have argued that the publication habit was more developed in Delphi than in other poleis. It provided a catalyst that stimulated foreign benefactors to compete in the race for honours, as it was better to be a recipient of a published decree in a Panhellenic sanctuary than to have your award hoarded in some nook at a local archive.

After discussing the various types of individual honours and privileges awarded to their recipients, Chapter 6 also examined the significance of locations where these awards were displayed, contributing to the ongoing discussion on relations between Greek epigraphic habits and the local urban spaces in which they developed. The placement of honorific statues and decrees within the Delphic temenos was not a random action but rather a precisely planned process which was influenced by several (variable) factors. These factors included the availability of space, the visibility of the monuments, the presence of a suitable neighbourhood and the number of visitors that could be expected. Overcrowding of the display space in Delphi also encouraged a race for visibility and monumentality. When placement alone could no longer guarantee prominence, other strategies were introduced to garner attention for statues, making it stand out from the forest of other portraits at Delphi. The first strategy was to set up a statue on a high column; the second was to raise portraits in groups; the third was to choose a proper neighbourhood that would attract numerous visitors; the fourth and final option concerned the increasing use of stoai in the period under discussion. All these strategies imprinted visible marks on the Delphic topography. Throughout nearly nine centuries of its use, the public space was divided, rearranged, overbuilt and razed during numerous attempts at controlling the Delphic territory. Perusal of over 700 years of the Delphic honorific habit is sufficient to demonstrate that not only monumental offerings and statues but also inscriptions gave organisation and continuity to the urban space.

This book as a whole provides a broad overview of both the Delphic culture of honouring and the honorific practices of other communities at Delphi, with particular attention paid to the Aetolian League, which dominated the Delphic statuary landscape much more effectively than any other community. The Aetolians not only competed in the sanctuary, but for the sanctuary. My 
examination of the Aetolian publication habit in Delphi showcased one of many aspects of the Aetolian domination over the sanctuary. To express its power, the League adopted the Delphic fashion of publishing state decrees; it carved its documents upon the Delphic building walls instead of on their own monuments. The cultural annexation of the public space on the western side of the Delphic temple, in direct contrast to its more prominent - and multiethnic - eastern counterpart, allowed the Aetolians to demarcate their private communal territory within the cosmopolitan Delphic temenos. The establishment of an exclusion zone, a space within a space, allowed the Aetolians to broadcast a clear message of superiority among the overcrowded and often confusing displays of statues and inscriptions. To the Delphic visitors, the Aetolian possession of a separate and exclusive display zone in a sanctuary spoke more of the League's power than did the Aetolians' seizure of control over the Delphic officials (agonothetai, epimeletai) or even the Amphictyonic council. Theirs was an unparalleled privilege and authority to shape the sacred cosmopolitan space as if they owned it, with no regard for any other power.

My material sample, which consisted of a rich array of varied honorific inscriptions, made it possible to examine several aspects of the honorific culture in post-classical Delphi, such as its decree culture, statuary and publishing habits, and the topography of honours. My tendency was to search for regularities, continuities, and rules underlying a wide range of local and international honorific practices. What I have read and seen led me to the conclusion that the Greek gift-giving system resembles a modern practice of tipping. A tip functions as a reward for good service but, simultaneously, as an encouragement for (e.g.) restaurant staff to treat their clients better in order to be rewarded in a near future. A tip (like a Greek honour) depends not only on a service provided (a specific benefaction), but also on who is being served (a polis granting honours). In general, waiters (or benefactors) tend to provide better service to clients whom they deem important and/or wealthy (poleis such as Athens or Delphi) in the hope for larger tips (or greater honours), as well as to their own families and friends (or the honorands' hometowns) who happened to visit a restaurant, in order to make them feel that someone is taking extra care of them.

In the introduction to this book, I stated that my intention was not to isolate Delphi but to discuss its gift-giving procedure alongside the honorific practices of other poleis and to ascertain whether the Delphic habit of honouring benefactors stood out in any manner or by and large paralleled other Hellenistic honorific procedures. Here, the following conclusions can be drawn. First, honouring local and foreign benefactors was a habit which the Delphians shared with other poleis, but the culture of publishing grants of honours was a local phenomenon which distinguished Delphi from its counterparts. The citizens 
of Delphi managed to perfect their publishing habit over time; this resulted in the production of thousands of inscriptions without excessive financial costs due to the use of abbreviated decrees and the fact that the walls of building were adopted as the setting for inscriptions. It should be noted that both of these practices have also been attested in other communities, but nowhere comes close to matching the scale of Delphi.

Second, the Delphic honorific culture shares many features with its Delian counterpart, with both poleis most commonly issuing proxeny decrees. Delos and Delphi established impressive proxeny networks in the third century BCE, focusing their honorific practices on foreigners rather than on their own inhabitants. Moreover, both locations benefitted from their association with renowned sanctuaries of Apollo.

Third, the Delphic honorific mode had clear parallels with honorific fashions of Boeotia (in particular that of Oropos) and, to some extent, the Aetolian League, implying a measure of uniformity in honorific practices of central mainland Greece. Having examined the material, I identified five main features typical of this area. (1) Many poleis in the region introduced epigraphy to their honorific practice in the fourth century в СЕ. The earliest epigraphic material recording local decrees in Delphi comes from the beginning of the fourth century вСE, which was more or less the same time that decrees granted by the Amphictyony and other poleis appeared at Delphi. To the best of our knowledge, neighbouring Boeotian poleis began to issue decrees at an unspecified point before the late fourth century вСЕ; Oropos first inscribed decrees in the 33OS BCE, whereas the Boeotian League started to produce them in the 36os. (2) The peak of the Delphic and Boeotian epigraphic curves both date to the third century вСЕ, with preserved decrees outnumbering tituli honorarii. (3) The range of the Delphic proxeny network was similar to the networks created by the League of the Aetolians during its heyday of the third and early second centuries BCE, and to the Oropean network. (4) Similarly to the Delphians, the Aetolians in Thermon abbreviated their decrees, while the Oropians inscribed theirs upon statue bases in lieu of more commonly used stelai. (4) Both the mainland Greek communities and Delphi showed similarities in their conferral of honours on women. The numbers of honours which these communities granted to their local benefactresses surpassed the numbers of honours granted to foreign benefactresses; furthermore, most of these grants date to the imperial period, the second century CE in particular.

Fourth, the Delphic language of honours is comparable to the documentary practice in other regions. Just as in Athens, so too in Delphi decrees were known as psephismata. As in the Peloponnesian communities, in Delphi documents rarely reveal the proposer of the motion. Finally, the terms used to describe commendable qualities of honorands in the motivation clause in 
Delphi closely resemble those used in other poleis, demonstrating that this aspect of the honorific language drew from a stock repertoire of phrases common to all Greek communities.

It is certainly possible that further common features between the honorific cultures of Delphi and other territories may come to light if the said territories yielded more honorific material. In contrast to Delphi, Olympia has provided very little information about its honorific culture, complicating any comparisons between these sanctuaries. ${ }^{2}$ Ostensibly, the wealth of the Delphic honorific evidence could provide parallels to the similarly rich honorific material recorded in Athens; nonetheless, my examination demonstrated beyond all doubt that these two epigraphic cultures diverged in many aspects, despite their proximity and strong ties (Chapters 3 and 4). These differences are particularly visible in the publishing habits. Citizens of Delphi commonly inscribed abbreviated decrees upon building walls located within the small temenos, whereas the Athenians carved full pattern decrees on stelai dislocated between the large territories of agora and Akropolis. Furthermore, Domingo Gygax has remarked that (Athenian) euergetism, an institution designed for foreigners, evolved to regulate and cement relationships both between Athenian masses and their elites (comprising a domestic aspect) and between the Athenian polis and foreign kings (comprising an international aspect). ${ }^{3}$ In contrast, the Delphic honorific culture focused on foreigners for centuries, with its inward turn (fostering commoner-elite relationships) dated only to the imperial period, hundreds of years after Athens.

The rich array of the surviving Delphic epigraphic material means that we, as ancient historians and epigraphists, are in a great position to reconstruct the honorific practice and social relations of Delphic society. Despite great strides made by epigraphists in their studies on Delphi, many aspects of the local honorific culture evade our understanding. In this study, I employed preserved honorific documents to investigate the honorific culture at Delphi from the early fourth century ВСE onwards; Herodotus implies, however, that awards of honours at Delphi first began in the mid-sixth century BCE, with no evidence left to corroborate or refute his claim. ${ }^{4}$ Tantalisingly, this larger picture still remains out of reach. It is my hope that this book will encourage scholars of the Greek honorific habit to adopt a broad interdisciplinary perspective when dealing with material originating in other, hitherto under-researched poleis, enhancing and furthering the general discussion on the awarding of honours in antiquity.

\footnotetext{
2 Komar 2020, 68-8o.

3 Domingo Gygax 2016, 251.

4 Hdt. 1.54 .
} 